\title{
Physiological Activity of the Glycyrrhiza uralensis Extracts as a Cosmetic Product
}

Kye Soon Kim, Min Jeong Ryu

Department of Cosmetology Science, Nambu University, Gwangju, Korea

\author{
*Corresponding author: Min Jeong Ryu, \\ Department of Cosmetology Science, \\ Nambu University, 23 Cheomdanjungang-ro, \\ Gwangsan-gu, Gwangju 62271, Korea \\ Tel.: +82629700137 \\ Fax: +82629726200 \\ Email: jemine0806@hanmail.net
}

Received September 23, 2016

Revised November 30, 2016

Accepted December 15, 2016

Published March 30, 2017

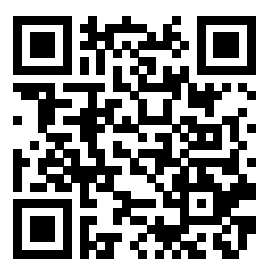

\begin{abstract}
Purpose: The aim of this study was to investigate the biological and cosmetic properties and the industrial value of the Glycyrrhiza uralensis (G. uralensis) extracts. Methods: The protective effects and anti-inflammatory efficacy of $G$. uralensis in HaCaT cells and RAW 264.7 cells against anti-oxidation and oxidative stress were analyzed, and the secretion of $\beta$-hexosaminidase, which plays a leading role in easing allergic symptoms, was measured. Moreover, anti-bacterial activity on human skin pathogens was measured. Ethanol (70\%) and hot water extraction were performed to make the extracts from domestically grown G. uralensis. Results: The comparison revealed that the $70 \%$ ethanol extracts were excellent in as antioxidants. Results of the cell experiment using the G. uralensis extracts showed that there was no significant cytotoxicity in HaCaT, RAW 264.7, or RBL$2 \mathrm{H} 3$ cells. In $\mathrm{HaCaT}$ cells, there was a $28 \%$ increase in the protective effects against oxidative stress caused by hydrogen peroxide $\left(\mathrm{H}_{2} \mathrm{O}_{2}\right)$ using a concentration of $100 \mu \mathrm{g} / \mathrm{mL}$ of the $70 \%$ ethanol extracts. The anti-inflammatory efficacy of the G. uralensis extracts on RAW 264.7 cells was checked, and it was found that the production of nitric oxide (NO) was inhibited, even low concentrations. The secretion of $\beta$-hexosaminidase was also measured, and it was found that $G$. uralensis and the ethanol and hot water extracts inhibited the degranulation of immune cells, depending on concentrations levels. It was confirmed that G. uralensis's antibacterial activity was even effective against Staphylococcus aureus (S. aureus), Staphylococcus epidermidis (S. epidermidis), and Propionibacterium acnes ( $P$. acnes) depending on the concentrations of used. Conclusion: Based on the findings of this study, the $G$. uralensis extracts are recommended as ingredients for sensitive skin cosmetics. A systematic study on verifying the efficacy of the $G$. uralensis extracts is further required through tests on humans and animals in order to determine the possibility of its clinical use.
\end{abstract}

Keywords: Glycyrrhiza uralensis, Bioactivity, Cosmetics, Anti-inflammatory effects, Anti-oxidation

\section{Introduction}

의학기술의 발달로 평균수명이 증가함으로써 삶의 질이 향상되 었고, 건강과 아름다움에 대한 관심도 점차 높아지고 있다. 더불어 주름이나 미백, 아토피, 여드름 등 피부미용에 대한 관심 또한 증가 하여(Kim et al., 2014), 천연물의 항균, 항산화, 미백 및 피부노화 억제 등을 목적으로 하는 연구가 활발히 이루어지고 있다. 특히 기
존의 화장품에 사용되고 있는 합성물질들은 피부의 알레르기를 일 으키거나 사람에 따라 유해한 영향을 미칠 수 있으므로 피부 자극 이나 안정성의 문제가 대두되면서 인체에 무해한 천연물질 소재에 관한 연구가 활발히 진행 중에 있다(Kim et al., 2010).

항균제는 사용 목적에 따라 방부제와 살균제로 나뉘며 화장품 의 보존성을 증가시키는 것 이외에도 피부를 청결히 하여 피부 상 재균 등 미생물의 생육을 억제하는 목적으로 화장품 제형 제조 시 
필수적으로 사용된다(Kim et al., 2010). 피부에 염증을 유발하는 피부 상재균은 대표적으로 $S$. aureus, P. acnes, Bacillus subtilis, Escherichia coli, Pseudomonas aeruginosa가 있으며 지루성 피부 염과 비듬을 유발하는 효모균인 Pityrosporum ovale 등이 있다. 여 드름은 성호르몬의 분비 증가에 따른 피지의 과도한 생성으로 발생 하는 염증 질환이며, 여드름균인 P. acnes는 지방분해효소(lipase)를 분비하여 피지를 유리 지방산으로 지질분해하고 모낭벽을 자극하여 모낭 및 그 주위에 여드름을 형성하는 것으로 알려져 있다(Park et al., 2010). S. aureus는 화농성 감염을 유발하며 아토피 피부염의 요 인으로 아토피 환자 중 90\%에서 발견되고 있다(Kim et al., 2013a).

염증반응은 피부손상 및 노화의 주요 원인이며, 이 과정은 체내 세포 조직에 어떠한 기질적 변화를 가져오는 침습이 가해질 때, 생 체가 재생이나 회복 등을 하기 위한 방어적 반응으로 나타나는 것 이다(Park et al., 2015). 이 과정에서 활성산소종(reactive oxygen species)의 일종인 $\mathrm{NO}$ 는 대식세포와 같은 면역세포에 의해 생성 되어 각종 생리 및 병리적 과정에 있어 중요한 역할을 한다(Lee et al., 2007). 알레르기 반응은 염증성 질환의 한 종류로, mast cell 이 탈과립되어 일어나는데 이때 히스타민이 분비된다. 히스타민은 mast cell에서 합성, 저장되고 급성 염증반응에 많은 영향을 끼치는 것으로 알려져 있으며, $\beta$-hexosaminidase는 히스타민과 mast cell 내에 함께 존재하는 효소로 탈과립에 의해 누출되는 히스타민의 양 과 비례하는 것으로 알려져 있어 항알레르기 효과 확인의 지표로서 이용되고 있다(Hong et al., 2014; Ryu, 2016).

감초 (G. uralensis)는 대략 6,000 년 전부터 약용식물로 동 - 서양 에서 쓰여져 왔으며, 쌍떡잎 식물 장미목 콩과에 속하는 다년생 초 본식물로서 높이는 약 30-70 $\mathrm{cm}$ 이며 간혹 $1 \mathrm{~m}$ 에 달하는 것도 있 다(Woo et al., 2006). 감초는 독성이 있는 약재성분을 완화시키고 여러 한약재가 조화롭게 어우러지도록 도와주는 약용식물로( $\mathrm{SeO}$ \& Choi, 2013), 천연복합물을 이용한 연구에 많이 보고되고 있다 (Jang et al., 2014; Jang \& Lee, 2014; Kim et al., 2011). 한편 국 내에 유통되는 감초의 대부분은 수입산이고, 현재 국내산 감초 추 출물을 화장품 원료로 사용한 예는 거의 없으며 국내산 감초의 대 부분은 식품산업 분야에서 이용되고 있는 실정이다(Kim et al., 2013b). 감초 추출물에 대한 국내 연구는 감초 추출물을 이용한 다 진 마늘의 갈변 저해 효과(Hwang et al., 2010), 감초 첨가에 의한 탁주의 저장성 및 품질 증진 효과(Kim et al., 2008), 동치미의 발 효숙성에 미치는 영향(Jang \& Moon, 1995), 궤양성 대장염 억제 효과(Lee \& Rhee, 2010) 등이 있다.

감초 추출물을 이용한 화장품 소재에 대한 연구는 감초의 tyrosinase 활성 억제 성분에 관한 연구가 있으며(Lee et al., 2003), Kim et al. (2014)의 원산지별 항균 활성, 정량 및 방부력에 관한 연구에서는 한국 감초가 중국, 우즈베키스탄 감초보다 높은 항균 활성이 확인되었으며, Han et al. (2013)의 원산지별 감초 추 출물의 항산화 활성 비교 연구에서도 한국 감초가 우수한 세포 보
호 효과를 나타내어 항산화 및 항노화 기능성 화장품 소재로서 다 양한 곳에 응용될 수 있음을 보고하였다. 본 연구에서는 국내산 감 초 추출물이 민감성 피부 보호용 미용제로의 가능성을 확인하기 위 하여 감초를 에탄올, 열수 추출하여 항산화 효과를 측정하였으며, $\mathrm{H}_{2} \mathrm{O}_{2}$ 에 의해 유발되는 산화적 스트레스에 대한 $\mathrm{HaCaT}$ 세포의 보 호 효과, 항염 효능을 분석하고, $\beta$-hexosaminidase의 억제량을 측정하여 항알레르기 효능을 확인하였다. 또한 피부 상재균에 대한 항균 활성도 측정하였다.

\section{Methods}

\section{1. 시료조제}

본 실험에 사용한 감초는 전남생약농업협동조합(Korea)에서 구입하였으며, 파쇄하여 시료로 사용하였다. 에탄올 추출( $70 \%$ ethanol extraction, $\mathrm{EE})$ 은 감초 $10 \mathrm{~g}$ 에 $70 \%$ 에탄올 $1 \mathrm{~L}$ 을 이용하 여 환류냉각 추출기로 $60^{\circ} \mathrm{C}$ 온도조건에서 $24 \mathrm{~h}$ 동안 추출하였고 열수 추출(hot water extraction, $\mathrm{HE}$ )은 감초 $10 \mathrm{~g}$ 을 정제수 $1 \mathrm{~L}$ 을 이용하여 환류냉각 추출기로 $90^{\circ} \mathrm{C}$ 온도조건에서 $24 \mathrm{~h}$ 동안 추출 하였다. 추출액은 여과지(Whatman No. 2; GE Healthcare Life Sciences, USA)를 사용하여 여과하였고, 감압농축기(EYELA N-1000; Tokyo Rikakikai, Japan)를 이용하여 감압 농축한 후 동결건조(FD5508; IlshinBioBase, Korea)하여 냉동 보관하였다.

\section{2. 세포주 및 세포배양}

본 실험에 사용한 $\mathrm{HaCaT}$ 세포, 마우스의 RAW 264.7 대식세포 그리고 Rat basophilic leukemia 세포주인 RBL-2H3 세포는 한국 세포주은행(Korea)에서 구입하였다. HaCaT 세포와 RAW 264.7 대 식세포는 Dulbecco's Modified Eagle Medium (DMEM; Gibco ${ }^{\mathrm{TM}}$, Thermo Fisher Scientific, USA), RBL-2H3 세포는 Minimun Essential Media (MEM; Gibco ${ }^{\mathrm{TM}}$, Thermo Fisher Scientific)에 각각 $10 \%$ fetal bovine serum (FBS; Gibco ${ }^{\mathrm{TM}}$, Thermo Fisher Scientific)과 $1 \%$ streptomycin/penicillin ( $\mathrm{HyClone}^{\mathrm{TM}}, \mathrm{GE}$ Heatlhcare Life Sciences)을 넣어 배양액으로 각각 $37^{\circ} \mathrm{C}, 5 \%$ $\mathrm{CO}_{2}$ 의 습윤화된 incubator에서 적응시켜 배양하였다.

\section{3. 폴리페놀 함량 분석}

폴리페놀 함량은 Folin \& Denis (1915) 방법에 따라, 추출물 $(1 \mathrm{mg} / \mathrm{mL}) 50 \mu \mathrm{L}$ 에 증류수 $650 \mu \mathrm{L}$ 넣고 Folin-Denis reagent (Sigma-Aldrich, USA)를 $50 \mu \mathrm{L}$ 을 가하여 $3 \mathrm{~min}$ 동안 실온에 서 반응시킨다. 반응시킨 후 $10 \%$ sodium carbonate (SigmaAldrich) 포화용액을 $100 \mu \mathrm{L}$ 첨가하고, 최종 볼륨을 $1 \mathrm{~mL}$ 맞추 기 위해 증류수 $150 \mu \mathrm{L}$ 넣어 잘 혼합시켰다. $37^{\circ} \mathrm{C}$ water bath에 $1 \mathrm{~h}$ 반응시킨 후 UV-Vis spectrophotometer (Ultrospec 2000; 
Pharmacia Biotech, Sweden)을 이용하여 $725 \mathrm{~nm}$ 에서 흡광도를 측정하였다. 표준곡선은 tannic acid (Sigma-Aldrich) 농도 0-500 $\mu \mathrm{g} / \mathrm{mL}$ 이 되도록 하고 이로부터 총 폴리페놀 함량을 구하였다.

\section{4. 플라보노이드 함량 분석}

플라보노이드 함량은 추출물 $(1 \mathrm{mg} / \mathrm{mL}) 100 \mu \mathrm{L}$ 에 $1 \mathrm{~mL}$ diethylene glycol (Sigma-Aldrich)을 첨가하고, 다시 $1 \mathrm{~N}$ sodium hydroxide (NaOH; Sigma-Aldrich) $100 \mu \mathrm{L}$ 넣어 잘 혼합시켜 $37^{\circ} \mathrm{C}$ water bath에 $1 \mathrm{~h}$ 반응시킨 후 UV-Vis spectrophotometer 을 이용하여 $420 \mathrm{~nm}$ 에서 흡광도를 측정하였다. 표준곡선은 naringin (Sigma-Aldrich) 농도를 0-300 $\mu \mathrm{g} / \mathrm{mL}$ 이 되도록 하여 작성하고 이로부터 총 플라보노이드 함량을 구하였다.

\section{DPPH radical 소거작용 측정}

2,2-Diphenyl-1-picrylhydrazyl (DPPH; Sigma-Aldrich) radical을 이용한 항산화 활성은 Blois (1958)의 방법을 약간 변형 하여 사용하였다. $1 \mathrm{mM} \mathrm{DPPH}$ 용액 $100 \mu \mathrm{L}$ 와 추출물(12.5-400 $\mu$ $\mathrm{g} / \mathrm{mL}$ )을 $100 \mu \mathrm{L}$ 씩 취하여 혼합한 후 $30 \mathrm{~min}$ 암 상태에서 방치한 후 잔존 radical 농도를 enzyme-linked immunosorbent assay (ELISA) reader (Molecular Devices, USA)를 이용하여 $517 \mathrm{~nm}$ 에서 측정하였다. 활성비교를 위하여 항산화 물질로 잘 알려진 butylated hydroxytoluene (BHT), L-ascorbic acid (vitamin C, vit. C)와 비교하였다. 전자공여능(\%)은 (1-시료의 흡광도/대조군 의 흡광도 $) \times 100(\%)$ 에 의하여 산출하였다.

\section{MTT assay를 이용한 세포독성 측정}

$\mathrm{HaCaT}$ 세포와 RAW 264.7 대식세포 그리고 RBL-2H3 세포 의 생존율 측정은 Mosmann (1983) 방법에 의하여 실시하였다. 96 well plate의 각 well에 logarithmic phase에 도달한 세포를 $1 \times 10^{5}$ cells/well의 농도가 되도록 조절하여 분주하여 $24 \mathrm{~h}$ 배양하여 부 착화 및 안정화를 시행하였다. $24 \mathrm{~h}$ 배양이 끝난 후 추출물을 최 종 농도 5-200 $\mu \mathrm{g} / \mathrm{mL}$ 가 되도록 배양액에 희석하여 부착 및 안정 화된 세포에 공급하고 $24 \mathrm{~h}$ 동안 배양하였다. 배양완료 후 well에 thiazolyl blue tetrazolium bromide (MTT; Sigma-Aldrich, 5 mg/ $\mathrm{mL}$ in phosphate buffered saline) 용액을 $10 \mu \mathrm{L}$ 씩 가해주고, 다 시 $37^{\circ} \mathrm{C}, 5 \% \mathrm{CO}_{2}$ 의 습윤 배양기에서 $4 \mathrm{~h}$ 동안 반응하여 MTT가 환원되도록 하였다. 각 well에 생성된 formazan 결정을 dimethyl sulfoxide $150 \mu \mathrm{L}$ 로 잘 녹여서 ELISA reader를 이용하여 $540 \mathrm{~nm}$ 에서 흡광도를 측정하였다.

\section{7. $\mathrm{H}_{2} \mathrm{O}_{2}$ 에 의하여 유발되는 산화적 스트레스에 대한 $\mathrm{HaCaT}$ 세포 보호 효과}

$\mathrm{H}_{2} \mathrm{O}_{2}$ 에 의해 유발되는 산화적 스트레스에 대한 $\mathrm{HaCaT}$ 세포의 보호 효과를 관찰하기 위하여 O'Toole et al. (1996) 방법을 응용하
여 실험하였다. 96 well plate에 $\mathrm{HaCaT}$ 세포를 $1 \times 10^{5}$ cells/well의 농도로 조절하여 $24 \mathrm{~h}$ 동안 배양한 후, 세포 생존율에 따라 추출물을 $2 \mathrm{~h}$ 전처리 후, 최종 농도가 $500 \mu \mathrm{M}$ 의 $\mathrm{H}_{2} \mathrm{O}_{2}$ 를 함유한 배양액을 투여 하여 $24 \mathrm{~h}$ 동안 반응시킨 다음 MTT assay로 생존율을 측정하였다.

\section{8. 항알레르기 활성 측정}

$\mathrm{RBL}-2 \mathrm{H} 3$ 세포를 24 well plate에 각각 $2 \times 10^{5}$ cells/well 의 세포가 들어가도록 분주한 다음, well 당 $25 \mathrm{ng} / \mathrm{mL}$ 의 antidinitrophenyl immunoglobulin E (anti-DNP IgE; Sigma-Aldrich) 로 감작시키고, $5 \%$ 의 $\mathrm{CO}_{2}$ 배양기에서 $12 \mathrm{~h}$ 배양시켰다. 세포를 siraganian buffer (119 mM sodium chloride, $5 \mathrm{mM}$ potassium chloride, $5.6 \mathrm{mM}$ glucose, $0.4 \mathrm{mM}$ magnesium chloride, $25 \mathrm{mM}$ piperazine-N,N'-bis (2-ethanesulfonic acid), $40 \mathrm{mM} \mathrm{NaOH}, 1$ $\mathrm{mM}$ calcium chloride, $0.1 \%$ bovine serum albumin, $\mathrm{pH}$ 7.2)로 2회 세척한 후 추출물을 농도별 $(5,10,20,50 \mu \mathrm{g} / \mathrm{mL})$ 로 첨가한 후 $37^{\circ} \mathrm{C}$ 에서 $30 \mathrm{~min}$ 동안 다시 반응시키고, 여기에 2-4-dinitrophenylhuman serum albumin (DNP-HSA; Sigma-Aldrich) 250 ng/mL 를 처리하고 $30 \mathrm{~min}$ 동안 알레르기 반응을 유도하였다. Ice bath에 서 $10 \mathrm{~min}$ 동안 반응을 정지시킨 후 $12,000 \mathrm{rpm}$ 에서 $3 \mathrm{~min}$ 원심분 리하여 상등액만 회수하여 $\beta$-hexosaminidase 측정에 이용하였다. $\beta$-Hexosaminidase 분비 저해 측정은 상등액 $30 \mathrm{~mL}$ 와 substrate buffer (2 mM 4-nitrophenyl-N-acetyl- $\beta$-D-glucosaminide, $0.05 \mathrm{M}$ sodium citrate, $\mathrm{pH} 4.5) 30 \mathrm{~mL}$ 을 혼합한 반응액을 $1 \mathrm{~h}$ 동 안 $37^{\circ} \mathrm{C}$ 에서 반응시키고, $0.1 \mathrm{M}$ carbonate buffer $250 \mathrm{~mL}$ 를 첨가 하여 반응을 종결시키고, ELISA reader를 사용하여 $405 \mathrm{~nm}$ 에서 흡광도를 측정하였다.

\section{Nitrite 생성량 측정}

Raw 264.7 세포로부터 생성된 NO의 양은 griess 시약을 이용 하여 세포배양액 중에 존재하는 nitrite $\left(\mathrm{NO}_{2}^{-}\right)$의 형태를 측정하였 다. 96 well plate에 well당 $1 \times 10^{5}$ cells $/ \mathrm{mL}$ 의 Raw 264.7 세포가 들 어있는 부유액 $100 \mu \mathrm{L}$ 를 접종하고, $24 \mathrm{~h}$ 배양한 후 배지를 제거하 고, 무혈청 배지에 최종농도가 각각 $5,10,20,50 \mu \mathrm{g} / \mathrm{mL}$ 으로 되 도록 시료를 처리한 후 염증 반응 유도 인자인 lipopolysaccharide (LPS) $1 \mu \mathrm{g} / \mathrm{mL}$ 를 처리하여 $24 \mathrm{~h}$ 배양하였다. 세포배양 상등액과 동량의 griess 시약을 혼합하여 96 well plate에서 $10 \mathrm{~min}$ 동안 반 응시킨 후, ELISA reader를 사용하여 $540 \mathrm{~nm}$ 에서 흡광도를 측정 하였다. Nitrite의 농도는 sodium nitrite $\left(\mathrm{NaNO}_{2}\right)$ 와 비교하였다.

\section{0. 균주 및 균주배양}

항균 실험에 사용한 균주는 피부 상재균 중 염증을 유발하는 S. aureus, S. epidermidis, P. acnes를 생물자원센터(Korea)에 서 구입하여 계대배양하여 사용하였다. 균주배양을 위한 배지 는 $S$. aureus와 $S$. epidermidis는 각각 nutrient broth (Becton, 


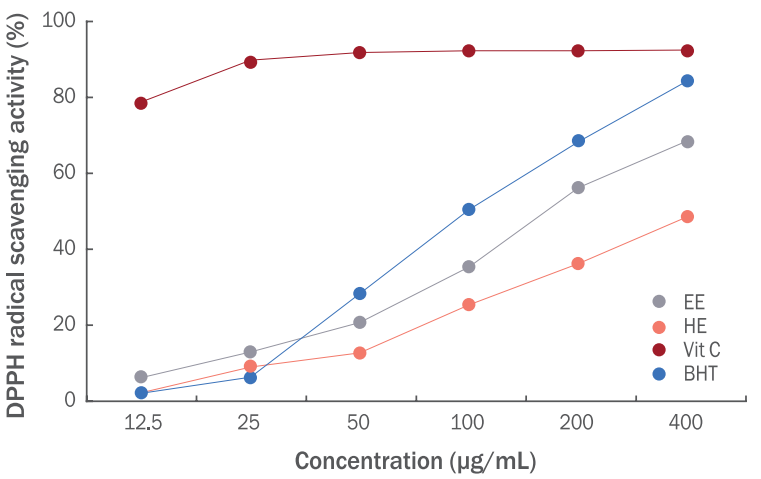

Figure 1. DPPH radical scavenging activities of the G. uralensis extracts.

2,2-Diphenyl-1-picrylhydrazyl (DPPH) radical scavenging assays were conducted to investigate the anti-oxidant effects of Glycyrrhiza uralensis (G. uralensis) ethanol (70\%) and hot water extracts at different concentrations of 12.5, 25, 50, 100, 200, and $400 \mu \mathrm{g} / \mathrm{mL}$, respectively. EE, 70\% ethanol extraction; HE, hot water extraction; Vit C, vitamin C; BHT, butylated hydroxytoluene. Vit C and $\mathrm{BHT}$ were used as positive controls.

Dickinson and Company, USA)를 사용하였으며 P. acnes의 배지 는 reinforced clostridial broth (Becton, Dickinson and Company) 를 사용하였다.

\section{Disc diffusion assay에 의한 항균 활성 측정}

감초 에탄올, 열수 추출물의 항균 활성은 시험 균주를 대상으 로 disc diffusion assay로 측정하였다. 배양된 균주는 $1 \times 10^{7} \mathrm{CFU} /$ $\mathrm{mL}$ 으로 조절한 후 본 실험에 사용하였다. 평판배지에 배양된 각 균 주를 $100 \mu \mathrm{L}$ 씩 도말하여 준비하였고, 감초 에탄올, 열수 추출물을 각각 $0.5,1,5,10 \mathrm{mg} / \mathrm{mL}$ 농도로 $40 \mu \mathrm{L}$ 씩 paper disc (diameter 8 $\mathrm{mm}$; Toyo Roshi kaisha, Japan)에 천천히 흡수시킨 뒤, 건조과정 을 거쳐 용매를 휘발시켰다. 대조군으로 에탄올을 사용하였다. 배양 후 disc 주변에 생성된 저해환(clear zone, $\mathrm{mm}$ )을 측정하여 항균 활 성을 비교하였다.

\section{2. 통계분석}

본 연구의 모든 실험 결과는 3 회이상반복하여 평균값으로 나타내었다. 대조군과 실험군사이의 통계학적 유의성 검정은 one-way analysis of variance (one-way ANOVA) 검정을 적용하였으며 $p<0.05$ 수준에서 유의성 검정을 실시하였다.

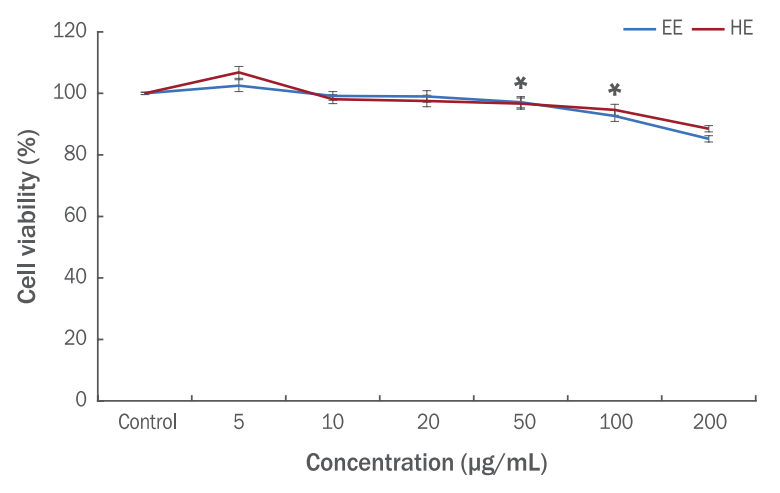

Figure 2. Effects of the G. uralensis extracts on the cell viability of HaCaT cells.

Cells were incubated with $G$. uralensis extracts $(5,10,20,50$, 100 , and $200 \mu \mathrm{g} / \mathrm{mL}$ ) for $24 \mathrm{~h}$ and cell viability was measured by thiazolyl blue tetrazolium bromide (MTT) assay. Results are represented as mean \pm standard deviation $(M \pm S$.D.) of the three independent experiments. *represents $p<0.05$ compared with control. EE, $70 \%$ ethanol extraction; $\mathrm{HE}$, hot water extraction; Control, untreated group.

\section{Results and Discussion}

\section{1. 총 폴리페놀 및 플라보노이드 함량}

천연물의 폴리페놀, 플라보노이드 등의 페놀성 물질의 함량에 비례하여 전자공여능 등의 항산화 활성이 증가한다는 많은 연구보 고에 따르면 페놀성 물질은 천연물의 항산화 효과 검증의 지표라고 할 수 있다. 때문에 천연물의 항산화 효과 검증에 관한 많은 연구에 서 폴리페놀 함량을 측정하였고, 폴리페놀 함량이 높을수록 항산화 효과가 뛰어남을 예측할 수 있다(Kang et al., 1996).

감초 에탄올 추출물과 열수 추출물의 총 폴리페놀 및 플라보 노이드 함량을 측정하여 Table 1에 결과를 나타내었다. Tannic acid 표준물질로 분석한 감초 에탄올, 열수 추출물의 총 폴리페놀 의 함량은 각각 $77.46 \pm 1.03,65.15 \pm 1.23 \mu \mathrm{g} / \mathrm{mL}$ 으로 나타났다. Naringin을 표준물질로 분석한 감초 에탄올, 열수 추출물의 총 플 라보노이드 함량은 $89.94 \pm 1.01,62.21 \pm 1.01 \mu \mathrm{g} / \mathrm{mL}$ 로 나타났다.

\section{DPPH radical 소거 활성}

$\mathrm{DPPH}$ 법은 항산화능을 측정하는 방법 중 하나로, $\mathrm{DPPH}$ 가 517 $\mathrm{nm}$ 에서 특이적인 흡수 band를 갖는 비교적 안정한 free radical이 라는 특성을 이용한다. 보라색의 $\mathrm{DPPH}$ 가 항산화능을 가진 물질로 부터 전자나 hydrogen radical을 받으면 환원되어 노란색으로 탈색 되고, 그 감소를 흡광도로 측정한다(Pak et al., 2016).

감초 에탄올, 열수 추출물을 농도별(12.5-400 $\mu \mathrm{g} / \mathrm{mL})$ 로 $\mathrm{DPPH}$ 용액에 첨가하여 free radical 소거 활성 능력을 측정한 결과, 에 탄올 추출물은 $6.20,12.98,20.74,35.40,56.25,68.62 \%$ 의 소 


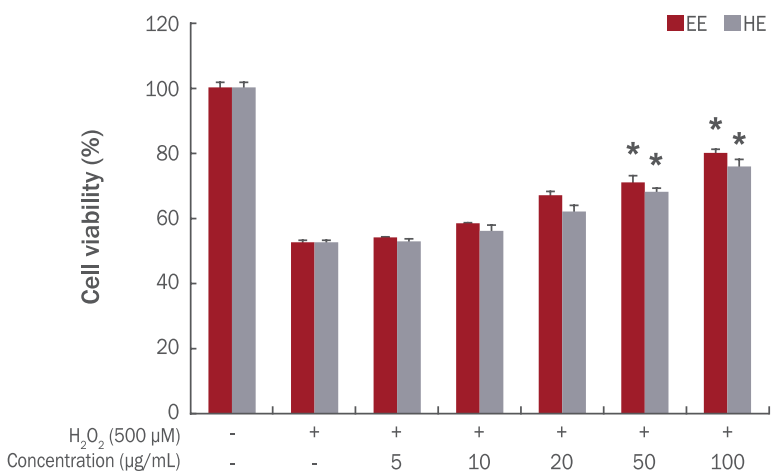

Figure 3. Protective effect of the $G$. uralensis extracts against oxidative stress induced by $\mathrm{H}_{2} \mathrm{O}_{2}$ in HaCaT cells.

Cells were incubated with $G$. uralensis extracts for $2 \mathrm{~h}$ followed by treatment with $500 \mu \mathrm{M}$ hydrogen peroxide $\left(\mathrm{H}_{2} \mathrm{O}_{2}\right)$ for $24 \mathrm{~h}$ and cell viability was measured by MTT assay. Results are represented as $\mathrm{M} \pm \mathrm{S}$.D. of the three independent experiments. "represents $p<0.05$ compared with control. EE, $70 \%$ ethanol extraction; $\mathrm{HE}$, hot water extraction; Control, untreated group.

거능이, 그리고 열수 추출물은 $2.20,8.98,12.74,25.40,36.25$, $48.62 \%$ 의 소거능이 확인되었다(Figure 1).

\section{3. 감초 추출물이 인체피부세포(HaCaT Cell)에 미치는 영향}

1) 세포 생존율 분석결과

감초 에탄올, 열수 추출물을 각각 $5-200 \mu \mathrm{g} / \mathrm{mL}$ 의 농도로 $\mathrm{HaCaT}$ 세포에 처리하여 MTT assay를 진행한 결과는 다음과 같다 (Figure 2). 감초 추출물은 $100 \mu \mathrm{g} / \mathrm{mL}$ 이하 농도범위에서 $90 \%$ 이 상의 생존율이 확인되었으므로 감초 추출물 모두 $100 \mu \mathrm{g} / \mathrm{mL}$ 농도 범위에서 세포독성을 보이지 않았다. 따라서 감초 에탄올, 열수 추 출물 5-100 $\mu \mathrm{g} / \mathrm{mL}$ 농도에서 $\mathrm{H}_{2} \mathrm{O}_{2}$ 에 의한 $\mathrm{HaCaT}$ 세포주의 보호 효과 측정 시 세포 사멸에 큰 영향을 주지 않는 것으로 분석되었다.

2) 산화적 스트레스 요인에 의한 감초 추출물의 세포 보호 효과 측정결과

$\mathrm{H}_{2} \mathrm{O}_{2}$ 는 산화적 스트레스를 유발시키는 물질로서 in vitro 실험에 서 독성 유발 물질로 자주 이용된다(Cho et al., 2014). HaCaT 세 포에 $\mathrm{H}_{2} \mathrm{O}_{2}$ 로 산화적 스트레스를 유발시켜 감초 에탄올 추출물과 열수 추출물에 대한 세포 생존율을 측정한 결과는 Figure 3 과 같 다. 대조군의 세포 생존율을 $100 \%$ 로 보았을 때 전처리하지 않은 실 험군은 $52.70 \%$ 세포 생존율을 나타낸 반면, 추출물의 농도가 높

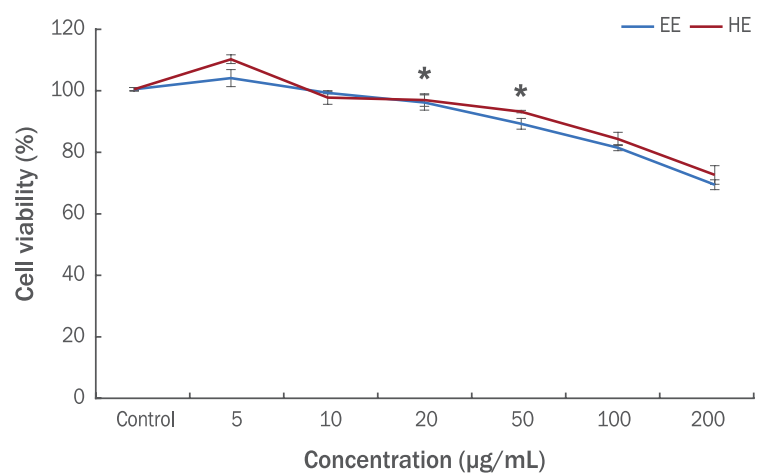

Figure 4. Effects of the G. uralensis extracts on the cell viability of RBL-2H3 cells.

Cells were incubated with $G$. uralensis extracts $(5,10,20,50$, 100 , and $200 \mu \mathrm{g} / \mathrm{mL}$ ) for $24 \mathrm{~h}$ and cell viability was measured by MTT assay. Results are represented as $\mathrm{M} \pm$ S.D. of the three independent experiments. *represents $p<0.05$ compared with control. EE, $70 \%$ ethanol extraction; $\mathrm{HE}$, hot water extraction; Control, untreated group.

아질수록 세포 생존율이 높게 나타났으며, 감초 에탄올 추출물의 경우 5-100 $\mu \mathrm{g} / \mathrm{mL}$ 의 농도에서 각각 $54.23,58.53,67.14,71.11$, $80.19 \%$ 생존율을 나타내어, $100 \mu \mathrm{g} / \mathrm{mL}$ 에서는 약 $28 \%$ 의 세포 보 호 효과가 확인되었다. 열수 추출물은 각각 $52.98,56.21,62.15$, $68.24,75.98 \%$ 의 생존율을 나타내었으므로 $100 \mu \mathrm{g} / \mathrm{mL}$ 의 농도에 서 약 $23 \%$ 의 세포 보호 효과를 확인하였다.

\section{4. 감초 추출물의 항알레르기 활성}

1) 세포 생존율 분석결과

비만세포는 천식, 비염, 아토피 피부염 등의 알레르기 질환 발생 에 중요한 역할을 한다(Jung et al., 2013). RBL-2H3 세포의 생 존율에 감초 에탄올 추출물과 열수 추출물이 미치는 영향을 알아 보기 위하여 MTT assay를 실시하였다. 감초 에탄올 추출물과 열 수 추출물 모두 $50 \mu \mathrm{g} / \mathrm{mL}$ 이하에서는 유의할만한 세포독성을 보 이지 않았다(Figure 4). 따라서 감초 에탄올, 열수 추출물 5-50 $\mu$ $\mathrm{g} / \mathrm{mL}$ 농도에서 $\beta$-hexosaminidase 분비 측정 시 세포 사멸에 큰 영향을 주지 않는 것으로 분석되었다.

\section{2) $\beta$-Hexosaminidase 분비에 감초 추출물이 미치는 영향} 항원과 항체가 비만세포에 반응하여 세포내에서 외부로 분비되

Table 1. Amount of total phenolics and flavonoids of the G. uralensis extracts

\begin{tabular}{lll}
\hline & EE & HE \\
Total phenolics & $77.46 \pm 1.03 \mu \mathrm{g} / \mathrm{mL}$ & $65.15 \pm 1.23 \mu \mathrm{g} / \mathrm{mL}$ \\
Total flavonoids & $89.94 \pm 1.01 \mu \mathrm{g} / \mathrm{mL}$ & $62.21 \pm 1.01 \mu \mathrm{g} / \mathrm{mL}$ \\
\hline
\end{tabular}

EE, 70\% ethanol extraction; $\mathrm{HE}$, hot water extraction. 


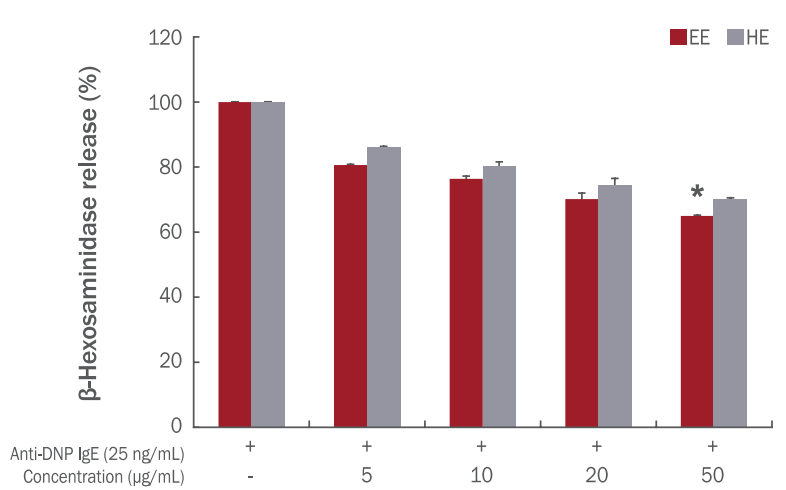

Figure 5. Inhibitory effects of $G$. uralensis extracts on the $\beta$-hexosaminidase release in IgE-antigen complex-stimulated RBL-2H3 cells.

$\beta$-Hexosaminidase release in IgE-antigen complex-stimulated $\mathrm{RBL}-2 \mathrm{H} 3$ cells was measured to investigate the inhibition effects of $G$. uralensis extracts at different concentrations of 5, 10, 20, and $50 \mu \mathrm{g} / \mathrm{mL}$, respectively. Results are represented as $\mathrm{M} \pm \mathrm{S}$. D. of the three independent experiments. " represents $p<0.05$ compared with control. EE, $70 \%$ ethanol extraction; HE, hot water extraction; Control, untreated group; Anti-DNP IgE, antidinitrophenyl immunoglobulin $\mathrm{E}$.

는 히스타민, 프로스타글란딘 등의 과립의 양을 측정하는 것은 항 알레르기 효과를 확인하기에 적합한 방법이다(Hong et al., 2014).

따라서 본 연구에서는 세포외로 분비된 $\beta$-hexosaminidase 분비량을 측정하여 감초 에탄올, 열수 추출물의 항알레르기 효 능을 확인하였다, 감초 에탄올, 열수 추출물의 처리 농도는 세포 생존율 측정 결과에 따라 세포에 영향을 미치지 않는 농도인 5 , $10,20,50 \mu \mathrm{g} / \mathrm{mL}$ 로 처리하였다. Anti-DNP IgE와 HSA에 의 해 활성화된 RBL- $2 \mathrm{H} 3$ 세포에서 분비된 탈과립의 양을 $100 \%$ 로 보았을 때 $5,10,20,50 \mu \mathrm{g} / \mathrm{mL}$ 농도로 감초 에탄올, 열수 추 출물을 처리하였을 때에는 항원과 항체에 의해 활성화된 세포 를 기준으로 에탄올 추출물은 $20,24,30,35 \%$, 열수 추출물은 $14,20,26,30 \%$ 억제율을 나타내었다. 추출물의 농도가 높아질 수록 $\beta$-hexosaminidase 방출에 대한 억제 효과도 향상되었다 (Figure 5).

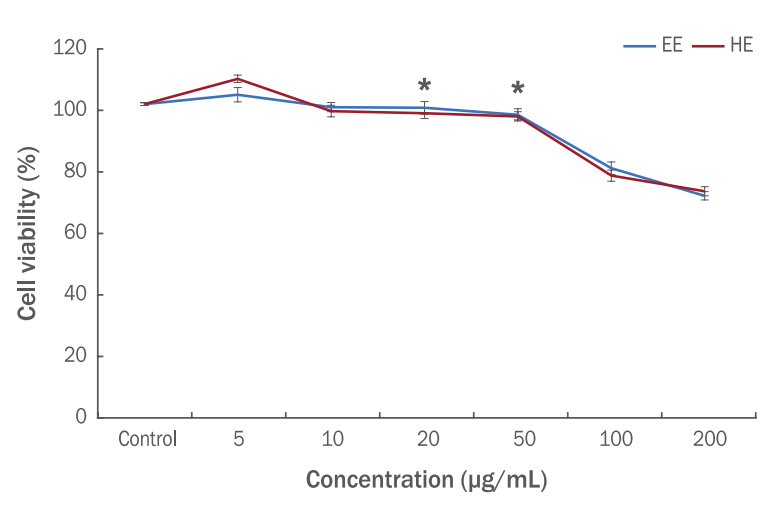

Figure 6. Effects of $G$. uralensis extracts on the cell viability of RAW 264.7 cells.

Cells were incubated with $G$. uralensis extracts $(5,10,20,50$, 100 , and $200 \mu \mathrm{g} / \mathrm{mL}$ ) for $24 \mathrm{~h}$. Results are represented as $\mathrm{M} \pm \mathrm{S}$. D. of the three independent experiments. * represents $p<0.05$ compared with control. EE, $70 \%$ ethanol extraction; $\mathrm{HE}$, hot water extraction; Control, untreated group.

\section{5. 감초 추출물의 항염 효과}

\section{1) 세포 생존율 분석결과}

감초 에탄올, 열수 추출물을 각각 5-200 $\mu \mathrm{g} / \mathrm{mL}$ 의 농도로 Raw 264.7 세포에 처리하여 MTT assay를 진행한 결과는 다음 과 같다(Figure 6). 감초 추출물은 $50 \mu \mathrm{g} / \mathrm{mL}$ 이하 농도범위에 서 $90 \%$ 이상의 생존율이 확인되었으므로 감초 추출물 모두 $50 \mu$ $\mathrm{g} / \mathrm{mL}$ 농도 범위에서 유의할만한 세포독성을 보이지 않았다. 따라서 감초 에탄올, 열수 추출물 $5-50 \mu \mathrm{g} / \mathrm{mL}$ 농도에서는 항염증 측정 시 세포사멸에 큰 영향을 주지 않은 것으로 분석되었다.

\section{2) NO 생성억제 효과}

활성산소 중 하나이며, 최근 염증 유발에 중요한 역할을 하는 것으 로 알려진 NO (Lee et al., 2006) 생성에 대한 감초 추출물의 효과를 알아보기 위하여 RAW 264.7 세포에 LPS로 자극을 주고, 에탄올, 열 수 추출의 감초 추출물을 처리하여 실험을 진행하였다. 생성된 NO 양은 griess 시약을 이용하여 세포배양액 중에 존재하는 $\mathrm{NO}_{2}{ }^{-}$를 측정 하여 확인하였다. 감초 추출물의 처리 농도는 세포 생존율 측정 결과

Table 2. Anti-microbial activity of the G. uralensis extracts on several microorganisms

\begin{tabular}{|c|c|c|c|c|c|c|c|c|c|}
\hline \multirow{3}{*}{ Microorganism } & \multicolumn{9}{|c|}{ Inhibition zone diameter (mm) } \\
\hline & \multicolumn{2}{|c|}{$5 \mathrm{mg} / \mathrm{mL}$} & \multicolumn{2}{|c|}{$1 \mathrm{mg} / \mathrm{mL}$} & \multicolumn{2}{|c|}{$0.5 \mathrm{mg} / \mathrm{mL}$} & \multicolumn{2}{|c|}{$0.25 \mathrm{mg} / \mathrm{mL}$} & \multirow{2}{*}{$\begin{array}{c}\text { Control } \\
\text { Ethanol }\end{array}$} \\
\hline & $\mathrm{EE}$ & $\mathrm{HE}$ & $\mathrm{EE}$ & $\mathrm{HE}$ & $\mathrm{EE}$ & $\mathrm{HE}$ & $\mathrm{EE}$ & $\mathrm{HE}$ & \\
\hline S. aureus & 15 & 13 & 14 & 13 & 12 & 10 & 10 & $-1)$ & - \\
\hline S. epidermidis & 15 & 14 & 13 & 11 & 11 & 11 & 10 & 10 & - \\
\hline P. acnes & 18 & 15 & 16 & 16 & 14 & 12 & 14 & 10 & - \\
\hline
\end{tabular}

\footnotetext{
${ }^{1)}$ No effects.
}

EE, 70\% ethanol extraction; HE, hot water extraction; S. aureus, Staphylococcus aureus; S. epidermidis, Staphylococcus epidermidis; P. acnes, Propionibacterium acnes. 


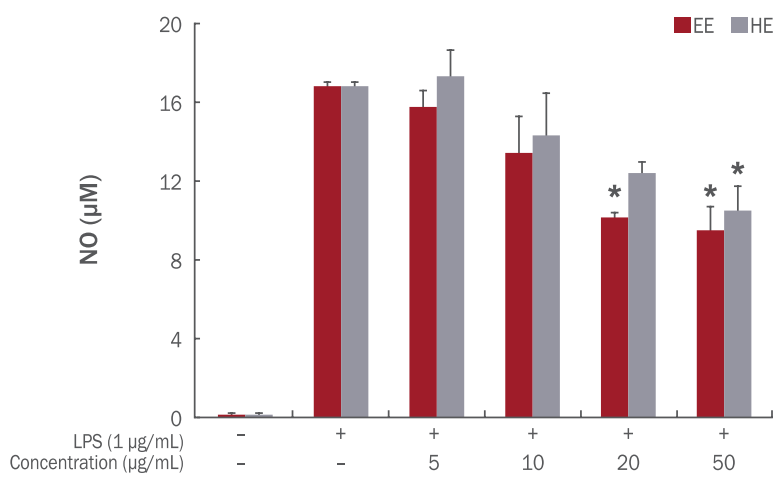

Figure 7. Effects of $G$. uralensis extracts on NO production in LPS-stimulated RAW 264.7 cells.

Cells were treated with different concentrations of the $G$. uralensis extracts for $1 \mathrm{~h}$, and stimulated with or without $1 \mu \mathrm{g} /$ $\mathrm{mL}$ lipopolysaccharide (LPS) for $24 \mathrm{~h}$. The nitric oxide (NO) concentration in the medium was determined by griess reagent. Results are represented as $M \pm S$.D. of the three independent experiments. *represents $p<0.05$ compared with control. EE, 70\% ethanol extraction; HE, hot water extraction; Control, untreated group.

에 따라 세포에 영향을 미치지 않는 농도인 5-50 $\mu \mathrm{g} / \mathrm{mL}$ 로 처리하였 다. LPS $(1 \mu \mathrm{g} / \mathrm{mL})$ 처리 후 NO의 생성량은 세포만 배양하였을 때 세 포배양에 비하여 약 16 배 이상 증가되었다. 감초 에탄올 추출물은 각 각 $15.70,13.40,10.15,9.50 \mu \mathrm{M}$ 로 측정되어 농도 의존적 및 유의적 으로 $\mathrm{NO}$ 생성이 억제되는 것으로 나타났으며 열수 추출물도 17.32 , $14.32,12.41,10.50 \mu \mathrm{M}$ 로 측정되어 농도 의존적이고 유의적으로 $\mathrm{NO}$ 생성이 억제되는 것으로 나타났다. 이와 같이 감초 에탄올 추출물과 열수 추출물은 농도 범위 내에서 모두 유의적으로 $\mathrm{NO}$ 생성을 감소 시키는 것으로 나타났다(Figure 7).

\section{6. 항균력 분석}

인간의 피부에 상주하는 다양한 균들에 의해서 많은 피부질환들 이 발생하고 있는데 그 중 가장 대표적인 질환으로는 비듬 및 지루 성 피부염, 여드름 그리고 무좀 등을 꼽을 수 있다(Ha et al., 2009). 염증성 여드름의 치료에 주로 사용되는 항생제는 tetracycline, clindamycin, erythromycin 등이 있으나, 오랜 기간 항생제를 사 용한 경우 내성이 생겨 치료효과가 떨어질 수 있다(Seong et al., 2003). 현재 비듬 및 지루성 피부염, 여드름에 사용되고 있는 합성 항균제와 과도한 항생제의 사용은 부작용과 안정성에 대한 문제를 야기시키고 피부에 알레르기를 유발할 수 있으므로 비교적 인체에 무해한 물질로 대체하기 위해 많은 연구들이 진행 중이다(Jang \& Lee, 2014).

화장품은 물과 고분자성 지질로 구성되어 세균 및 진균에 탄 소원과 질소원을 제공하는 미생물의 영양원으로 이용 될 수 있기 때문에 잘못 보관할 경우 미생물에 오염되기 쉽다(Lim \& Hong,
2016). 오염된 화장품은 미생물의 대사산물에 의해 지방산과 탄화 수소, 아미노산 유도체들이 변성되어 변취, 변색, 물성을 변화시켜 상품가치를 떨어트린다. 또한 화장품 사용 중에 오염이 된다면 지 속적으로 사용하는 화장품의 특성상 피부에 미생물이 감염되어 질 병을 일으킬 수 있다(Lee \& Shin, 2015).

본 실험에 사용된 균주는 피부염을 일으키는 균주로서, 그람양 성균인 $S$. aureus, S. epidermidis, P. acnes를 선별하여 paper disc 방법으로 측정한 결과는 Table 2에 나타내었다. 감초 에탄올, 열수 추출물을 농도 별로 처리한 결과, $S$. aureus에서 최대농도에 서는 각각 $15,13 \mathrm{~mm}$ 의 clear zone을 형성하였으며, 농도 의존적인 항균 활성을 나타내었고, S. epidermidis에서도 최대농도에서 각각 $15,14 \mathrm{~mm}$ clear zone을 형성하여 높은 항균 활성을 나타내었다. P. acnes에서도 최대농도에서는 각각 $18,15 \mathrm{~mm}$ 로 농도 의존적으 로 clear zone을 형성하여 가장 우수한 항균 활성을 나타내었다.

이러한 결과를 통해 감초 추출물은 여드름, 아토피, 지루성 피부 염과 관련된 균에 대한 항균 효과가 우수함을 알 수 있었다.

\section{Conclusion}

본 연구는 감초를 $70 \%$ 에탄올 및 열수로 추출하여, 추출물의 항 산화 효과를 확인하기 위하여 폴리페놀과 플라보노이드 함량을 측 정하였으며, $\mathrm{DPPH}$ radical 소거 활성을 측정하였다. $\mathrm{H}_{2} \mathrm{O}_{2}$ 에 의해 유발되는 산화적 스트레스에 대한 $\mathrm{HaCaT}$ 세포의 보호 효과, 항염 효능을 분석하고, $\beta$-hexosaminidase의 억제량을 측정하여 항알 레르기 효능을 확인하였다. 또한 항균 효능을 확인하기 위하여 $S$. aureus, S. epidermidis, P. acnes 균주들을 이용하여 실험을 진 행하였다.

감초 에탄올 추출물과 열수 추출물의 총 페놀 및 플라보노이드 함량을 측정한 결과, 감초 에탄올 추출물에서 각각 $77.46 \pm 1.03$ (페놀), 89.94 1.01 (플라보노이드) $\mu \mathrm{g} / \mathrm{mL}$ 으로 높게 나타났으며, $\mathrm{DPPH}$ radical 소거 활성에서도 에탄올 추출물이 $400 \mu \mathrm{g} / \mathrm{mL}$ 의 농 도에서 $68.62 \%$ 의 소거능이 확인되었다. 감초 추출물이 $\mathrm{HaCaT}$ 세 포에 미치는 영향을 분석하기 위해 세포 생존율을 측정한 결과, $100 \mu \mathrm{g} / \mathrm{mL}$ 이하의 농도에서는 $90 \%$ 이상의 생존율이 확인되어 $500 \mu \mathrm{M} \mathrm{H}_{2} \mathrm{O}_{2}$ 로 산화적 스트레스를 유발 시켜 감초 에탄올 추출물 과 열수 추출물에 대한 세포 생존율을 측정한 결과, 감초 에탄올, 열수 추출물 모두 농도 의존적으로 $\mathrm{HaCaT}$ 세포의 보호 효과가 확 인되었다.

$\beta$-Hexosaminidase 분비량을 측정하여 감초 에탄올과 열수 추 출물의 항알레르기 효능을 확인한 결과, 에탄올 추출물은 최대 $35 \%$, 열수 추출물은 최대 $30 \%$ 의 억제율을 나타내었다. Raw 264.7 세포에 독성을 미치지 않은 $50 \mu \mathrm{g} / \mathrm{mL}$ 이하의 농도로 $\mathrm{NO}$ 생성억 제 효과를 측정한 결과, 감초 에탄올 추출물과 열수 추출물은 농도 
범위 내에서 모두 유의적으로 NO 생성을 감소시키는 것으로 나타 났다. 피부염을 일으키는 $S$. aureus, S. epidermidis, P. acnes를 선별하여 paper disc 방법으로 측정한 결과, $P$. acnes 균에서 가장 우수한 항균 활성이 나타났다.

이상의 결과를 통해 감초 추출물은 항알레르기 활성 및 항염 효 과가 우수하며, 여드름, 아토피 지루성 피부염과 관련된 균에 대한 항균 효과가 우수하여 민감성 화장품 소재로서 우수한 효능이 확인 되었으며, 향후 임상적 활용 가능성을 판단하기 위하여 동물, 인체 시험을 통한 감초 추출물의 효능 검증 연구가 체계적으로 진행되어 야 할 것이다.

\section{Acknowledgements}

본 연구는 2016년도 남부대학교 학술연구비의 지원을 받아 연구 되었음.

\section{References}

Blois MS. Antioxidant determinations by the use of a stable free radical. Nature, 181: 1199-1200, 1958.

Cho BO, Lee CW, So Y, Jin CH, Yook HS, Byun MW, Jeong YW, Park JC, Jeong IY. Protective effect of radiation-induced new blackberry mutant $\mathrm{y}$-B201 on $\mathrm{H}_{2} \mathrm{O}_{2}$-induced oxidative damage in HepG2 cells. Korean Journal of Food Science and Technology, 46: 384-389, 2014.

Folin O, Denis W. A colorimetric method for the determination of phenols (and phenol derivatives) in urine. The Journal of Biological Chemistry, 22: 305-308, 1915.

Ha YM, Lee BB, Bae HJ, Je KM, Kim SR, Choi JS, Choi IS. Antimicrobial activity of grapefruit seed extract and processed sulfur solution against human skin pathogens. Journal of Life Science, 19: 94-100, 2009.

Han SB, Gu HA, Kim SJ, Kim HJ, Kwon SS, Kim HS, Jeon SH, Hwang JP, Park SN. Comparative study on antioxidative activity of Glycyrrhiza uralensis and Glycyrrhiza glabra extracts by country of origin. Journal of the Society of Cosmetic Scientists of Korea, 39: 1-8, 2013.

Hong IK, Kim EJ, Seok JH, Kim BH, Jang JD, Joe GJ, Choi SW. Effects of Eucommia ulmoides Oliver extract on inhibition of $\beta$-hexosaminidase and keratinocyte differentiation. Journal of the Society of Cosmetic Scientists of Korea, 40: 21-28, 2014.

Hwang TY, Sohn KH, Lim JH, Moon KD. Antibrowning effect of licorice (Glycyrrhiza glabra) extracts on chopped galic.
Korean Journal of Food Preservation, 17: 160-164, 2010.

Jang MS, Moon SW. Effect of licorice root (Glycyrrhiza uralensis Fischer) on Dongchimi fermentation. Journal of the Korean Society of Food Science and Nutrition, 24: 744-751, 1995.

Jang YA, Kim BA, Kim DH, Lee JT. Anti-inflammatory effects of Glyrrhizia uralensis Fisch, Forsythia suspensa Vahl, Coptis chinensis Franch and chestnut shells mixture and stability evaluation of cosmetics. Journal of the Korean Society of Cosmetology, 20: 827-833, 2014.

Jang YA, Lee JT. An investigation into antioxidant effects of Glycyrrhiza uralensis Fisch, Forsythia suspensa Vahl, Coptis chinensis Franch and antibacterial activities against cutaneous microorganisms. Journal of the Korean Society of Cosmetology, 20: 247-252, 2014.

Jung EM, Kim JW, Park MJ, Lee SS, Choi DH, Lee J, Jeung EB. Inhibitory effect of extracts from Rhododendron brachycarpum and Abies koreana E.H. Wilson on degranulation and cytokine expression in RBL-2H3 cells. Journal of the Korean Wood Science and Technology, 41: 551-558, 2013.

Kang YH, Park YK, Lee GD. The nitrite scavenging and electron donating ability of phenolic compounds. Korean Journal of Food Science and Technology, 28: 232-239, 1996.

Kim AR, Lee SY, Kim KBWR, Song EJ, Kim JH, Kim MJ, Ji KW, Ahn IS, Ahn DH. Effect of Glycyrrhiza uralensis on shelflife and quality of takju. Korean Journal of Food Science and Technology, 40: 194-200, 2008.

Kim HJ, Bae JY, Jang HN, Park SN. Comparative study on the antimicrobial activity of Glycyrrhiza uralensis and Glycyrrhiza glabra extracts with various countries of origin as natural antiseptics. Microbiology and Biotechnology Letters, 41: 358-366, 2013a.

Kim HJ, Jang HN, Bae JY, Ha JH, Park SN. Antimicrobial activity, quantification and bactericidal activities of licorice active ingredients. Microbiology and Biotechnology Letters, 42: 386-392, 2014.

Kim HJ, Jang HN, Bae JY, Park SN. A study on the stability of the cream containing Glycyrrhiza uralensis extract. Journal of the Society of Cosmetic Scientists of Korea, 39: 117-125, 2013b.

Kim SY, Lee MH, Jo NR, Park SN. Antibaterial activity and skin moisturizing effect of Cedrela sinensis A. Juss shoots extracts. Journal of the Society of Cosmetic Scientists of 
Korea, 36: 315-321, 2010.

Kim YH, Lee CE, Kim BS. Study on cytotoxicity test and antioxidant activity of herb complex (Phellinus linteus, Glycyrrhiza uralensis Fischer and Centella asiatica). Journal of the Korean Society of Cosmetology, 17: 441446, 2011.

Lee BH, Baik DS, Yun SU, Shin JM, Kim JH, Yun SY, Kim BH Kim SB, Shin JE, Song IH. Peripheral nitric oxide activity in patients with liver cirrhosis. The Korean Journal of Medicine, 73: 251-257, 2007.

Lee HJ, Kang GJ, Yoon WJ, Kang HK, Kim YS, Kim SM, Yoo ES. Anti-inflammatory effect of unripe fruit of Citrus grandis Osbeck in RAW 264.7 and HaCaT cells. Korean Journal of Pharmacognosy, 37: 74-80, 2006.

Lee HS, Shin MS. Antimicrobial effect of Luffa cylindrica extract against 4 skin microorganisms. Journal of the Korean Society of Cosmetology, 21: 471-476, 2015.

Lee JS, Kim JA, Cho SH, Son AR, Jang TS, So MS, Chung SR, Lee SH. Tyrosinase inhibitors isolated from the roots of Glycyrrhiza glabra L. Korean Journal of Pharmacognosy, 34: 33-39, 2003

Lee KH, Rhee KH. Anti-inflammatory effects of Glycyrrhiza glabra Linne extract in a dextran sulfate sodium-induced colitis mouse model. The Korean Journal of Food and Nutrition, 23: 435-439, 2010.

Lim MH, Hong S. Availability of Opuntia ficus-indica var. saboten stem extracts as a natural preservative. Asian Journal of Beauty and Cosmetology, 14: 449-461, 2016.

Mosmann T. Rapid colorimetric assay for cellular growth and survival: application to proliferation and cytotoxicity assays. Journal of Immunological Methods, 65: 55-63, 1983.
O'Toole EA, Goel M, Woodley DT. Hydrogen peroxide inhibits human keratinocyte migration. Dermatologic Surgery, 22: 525-529, 1996.

Pak WM, Kim KBWR, Kim MJ, Park JH, Bae NY, Park SH, Ahn DH. Anti-melanogenesis and anti-wrinkle effects of Sargassum micracanthum extracts. Microbiology and Biotechnology Letters, 44: 19-25, 2016.

Park JO, Park JO, Joo CG. A study on whitening and antiinflammatory effects of Eriobotrya japonica leaf extracts with different extraction methods. Journal of the Society of Cosmetic Scientists of Korea, 41: 151-157, 2015.

Park SJ, Park Cl, Kim SC. Antimicrobial activities of ethanolic extracts of marine resources against Propionibacterium acnes. The Korea Journal of Herbology, 25: 65-70, 2010.

Ryu MJ. Anti-stress and anti-histamine effects of Phragmites communis, Salicornia herbacea, and Prunus mume. Asian Journal of Beauty and Cosmetology, 14: 147-157, 2016.

Seo SH, Choi MO. Protectvie effects of Lonicerae japonicae Flos against hydrogen peroxidase-induced oxidative stress on human keratinocyte, HaCaT cells. The Korea Journal of Herbology, 28: 57-62, 2013.

Seong JM, Park NY, Lee SH. Effect of Schizandra chinensis and pine neddle on growth of pathogens relate to acne. Microbiology and Biotechnology Letters, 31: 69-74, 2003.

Woo KS, Jang KI, Kim KY, Lee HB, Jeong HS. Antioxidative activity of heat treated licorice (Glycyrrhiza uralensis Fisch) extracts. Korean Journal of Food Science and Technology, 38: 355-360, 2006. 


\section{국문초록}

\section{화장품 소재로서 감초 추출물의 생리활성}

김계순, 유민정

남부대학교 향장미용학과, 광주, 한국

목적: 감초 추출물에 대하여 생리활성 및 화장품 소재로서의 가능성과 산업적 활용가치를 확인하고자 하였다. 방법: 국내산 감초를 $70 \%$ 에탄올 및 열수 추출하여, 항산화, 산화적 스트레스에 대한 $\mathrm{HaCaT}$ 세포의 보호 효과, 항염 효능을 분석하고, $\beta$-hexosaminidase 의 억제량을 측정하여 항알레르기 효능을 확인하였다. 또한 피부 상재균에 대한 항균 활성도 측정하였다. 결과: 항산화력을 비교 한 결과, $70 \%$ 에탄올 추출물이 열수 추출물보다 우수하였으며, 감초 추출물을 이용한 세포 실험을 진행한 결과 HaCaT, RAW 264.7, RBL-2H3 세포에서 유의한 세포독성은 나타나지 않았다. Hydrogen peroxide $\left(\mathrm{H}_{2} \mathrm{O}_{2}\right)$ 에 의해 유발되는 산화적 스트레 스에 대한 $\mathrm{HaCaT}$ 세포의 보호 효과를 확인한 결과, $70 \%$ 에탄올 추출물 $100 \mu \mathrm{g} / \mathrm{mL}$ 의 농도에서 $28 \%$ 의 보호 효과가 확인되 었다. RAW 264.7 세포에 대한 감초 추출물의 항염 효과를 확인한 결과, 저농도에서도 nitric oxide (NO) 생성이 억제되었다. $\beta$ -Hexosaminidase의 분비를 측정한 결과, 감초 에탄올 추출물과 열수 추출물은 농도 의존적으로 면역세포의 탈과립을 억제하였다. Staphylococcus aureus (S. aureus), Staphylococcus epidermidis (S. epidermidis), Propionibacterium acnes (P. acnes) 균에서도 감초 추출물은 농도 의존적으로 항균 활성이 확인되었다. 결론: 본 연구는 감초 추출물의 기능성 화장품 소재로 사 용 시 민감성 화장품 소재로서 사용하는 것을 제안하며 향후 임상적 활용 가능성을 판단하기 위하여 동물, 인체시험을 통한 감초 추출 물의 효능 검증 연구가 체계적으로 진행되어야 할 것이다.

핵심어: 감초, 생리활성, 화장품, 항염 효과, 항산화

본 연구는 2016년도 남부대학교 학술연구비의 지원을 받아 연구되었음.

\section{참고문헌}

강윤한, 박용곤, 이기동. 페놀성 화합물의 아질산염 소거 및 전자공여 작용. 한국식품과학회지, 28: 232-239, 1996. 김선영, 이민혜, 조나래, 박수남. 참죽나무 새순 추출물의 항균 활성과 피부 보습효과에 관한 연구. 대한화장품학회지, 36 :

315-321, 2010.

김아람, 이소영, 김꽃봉우리, 송유진, 김진희, 김미정, 지경원, 안임숙, 안동현. 감초 첨가에 의한 탁주의 저장성 및 품질증진

효과. 한국식품과학회지, 40: 194-200, 2008.

김영훈, 이창언, 김병소. 천연복합물(상황버섯, 감초, 병풀)의 항산화 및 세포독성에 관한 연구. 한국미용학회지, 17: 441-

446, 2011.

김혜진, 배정윤, 장하나, 박수남. 원산지별 감초 추출물의 항균 활성 비교 및 천연방부제로써의 효능 연구. 한국미생물 - 생명 공학회지, 41: 358-366, 2013a.

김혜진, 장하나, 배정윤, 박수남. 한국산 감초 추출물 함유 크림의 안정성 평가. 대한화장품학회지, $39: 117-125,2013 b$.

김혜진, 장하나, 배정윤, 하지훈, 박수남. 감초 성분의 항균활성, 정량 및 방부력에 관한 연구. 한국미생물 - 생명공학회지,

42: 386-392, 2014.

박숙자, 박찬익, 김상찬. 해양 유래 한약재의 여드름균에 대한 항균 효능 연구. 대한본초학회지, 25: 65-70, 2010.

박원민, 김꽃봉우리, 김민지, 박지혜, 배난영, 박선희, 안동현. 잔가시 모자반 추출물의 주름 개선 및 미백 효과. 한국미생

물·생명공학회지, 44: 19-25, 2016.

박정옥, 박진오, 주철규. 추출 방법에 따른 비파엽 추출물의 미백 및 항염활성에 관한 연구. 대한화장품학회지, $41: 151-$ 
157, 2015.

서승희, 최미옥. Hydrogen peroxide로 산화적 스트레스가 유도된 HaCaT keratinocyte에서 금은화의 세포 보호 효과. 대한

본초학회지, 28: 57-62, 2013.

성준모, 박나영, 이신호. 여드름 원인균의 성장에 미치는 오미자와 솔잎의 효과. 한국미생물 · 생명공학회지, 31: 69-74, 2003. 우관식, 장금일, 김광엽, 이희봉, 정헌상. 열처리한 감초추출물의 항산화활성. 한국식품과학회지, 38: 355-360, 2006.

유민정. 갈대, 함초, 매실 추출물이 항스트레스 및 항히스타민 작용에 미치는 영향. 아시안뷰티화장품학술지, 14: 147-157, 2016. 이경호, 이기형. 감초 추출물의 Dextran Sulfate Sodium 유도 마우스 궤양성 대장염 억제효과. 한국식품영양학회지, 23 :

435-439, 2010.

이보한, 백두산, 윤승욱, 신재민, 김지환, 윤세영, 김병하, 김석배, 신정은, 송일한. 간경변증 환자에서 말초혈액 Nitric Oxide

활성도 측정의 의의. 대한내과학회지, 73: 251-257, 2007.

이주상, 김정아, 조세훈, 손애량, 장태수, 소명숙, 정시련, 이승호. 감초의 Tyrosinase 활성 억제 성분. 생약학회지, $34: 33-$

39, 2003.

이현숙, 신미숙. 수세미외 에탄올 추출물의 4종 피부균주에 대한 항균 효과. 한국미용학회지, 21: 471-476, 2015.

이혜자, 강경진, 윤원종, 강희경, 김영석, 김소미, 유은숙. RAW 264.7 및 $\mathrm{HaCaT}$ Cell에서 당유자 미숙과의 염증억제 효과.

생약학회지, 37: 74-80, 2006.

임미혜, 홍세정. 백년초 줄기 추출물의 화장품용 천연 방부제로서의 활용성. 아시안뷰티화장품학술지, 14: 449-461, 2016. 장명숙, 문성원. 감초 첨가가 동치미의 발효숙성에 미치는 영향. 한국식품영양과학회지, 24: 744-751, 1995.

장영아, 김보애, 김동희, 이진태. 감초, 연교, 황련, 율피 복합물의 항염증 효능 및 화장품의 안정성 평가. 한국미용학회지,

20: 827-833, 2014.

장영아, 이진태. 감초, 연교 황련의 항산화 및 피부상재균에 대한 항균력 조사. 한국미용학회지, 20: 247-252, 2014.

정의만, 김재우, 박미진, 이성숙, 최돈하, 이정복, 정의배. 만병초와 구상나무 추출물의 RBL- $2 \mathrm{H} 3$ 세포 탈과립, 싸이토카인

유전자 발현에 미치는 영향. 목재공학, 41: 551-558, 2013.

조병옥, 이창욱, 소양강, 진창현, 육홍선, 변명우, 정용욱, 박종천, 정일윤. $\mathrm{H}_{2} \mathrm{O}_{2}$ 에 의해 유도된 $\mathrm{HepG2}$ 세포의 산화적 스트레

스에 대한 신품종 방사선 돌연변이 블랙베리 $\gamma$-B201의 세포 보호 효과. 한국식품과학회지, 46: 384-389, 2014.

하유미, 이보배, 배희정, 제경모, 김순래, 최재석, 최인순. 피부질환 원인균에 대한 자몽종자추출물과 법제유황수의 항균 효과.

생명과학회지, 19: 94-100, 2009.

한샛별, 구현아, 김수지, 김혜진, 권순식, 김해수, 전소하, 황준필, 박수남. 원산지별 감초 추출물의 항산화 활성 비교 연구.

대한화장품학회지, 39: 1-8, 2013.

홍인기, 김은지, 석지현, 김보현, 장진동, 조기정, 최신욱. $\beta$-Hexosaminidase 분비 억제 및 각질형성세포 분화에 대한 두충

(Eucommia ulmoides Oliver) 추출물의 효과. 대한화장품학회지, 40: 21-28, 2014.

황태영, 손경현, 임정호, 문광덕. 감초추출물을 이용한 다진 마늘의 갈변 저해 효과. 한국식품저장유통학회지, 17: 160-164, 2010. 


\section{中文摘要}

\section{甘草提取物作为化妆品原料的生理活性}

金桂順，柳敏貞*

南部大学香匠美容學科, 光州, 韩国

目的：探讨甘草提取物的生理活性，确认甘草提取物作为化妆品原料的可行性和产业价值。方法：利用 $70 \%$ 乙醇和热水 提取法对国产甘草进行提取。并分析提取物的抗氧化，对氧化应激状态的HaCaT细胞的保护效果以及抗炎效能，并测定 ß-hexosaminidase的分泌抑制量，确认其抗过敏效能。此外，对人体皮肤病原菌的抗菌活性进行测定。结果: 抗氧化能力 比较显示, $70 \%$ 乙醇提取物的抗氧化能力比热水提取物更优秀。甘草提取物的细胞实验结果表明, 在HaCaT、RAW 264.7、 RBL-2H3细胞中没有产生明显的细胞毒性。甘草提取物对hydrogen peroxide $\left(\mathrm{H}_{2} \mathrm{O}_{2}\right)$ 诱发产生氧化应激的HaCaT细胞的保护 效果结果显示, $70 \%$ 乙醇提取物在 $100 \mu \mathrm{g} / \mathrm{mL}$ 中具有 $28 \%$ 的保护效果。甘草提取物对RAW 264.7 细胞的抗炎效果进行检查, 发现即使在低浓度也能抑制nitric oxide (NO)的形成。对 $\beta$-hexosaminidase的分泌情况测定结果, 甘草乙醇提取物和热水 提取物根据浓度水平抑制免疫细胞的脱颗粒。在Staphylococcus aureus (S. aureus)、Staphylococcus epidermidis (S. epidermidis)、Propionibacterium acnes (P. acnes)菌中根据甘草提取物的浓度水平显现抗菌活性。结论: 通过研究, 甘草 提取物作为功效性化妆品原料使用时, 被推荐使用为敏感性化妆品原料, 将来为判断临床应用的可能性, 需进行动物及人体 试验, 对甘草提取物的疗效需进行进一步系统研究。

关键词: 甘草, 生理活性, 化妆品, 抗炎, 抗氧化 